\title{
Application of Fmoc-SPPS, thiol-maleimide conjugation and copper(I)-catalyzed alkyne-azide cycloaddition "click" reaction in the synthesis of a complex peptide-based vaccine candidate against Group A Streptococcus
}

Chuankai Dai ${ }^{1}$, Rachel J. Stephenson ${ }^{1}$, Mariusz Skwarczynski ${ }^{1}$ and Istvan Toth $^{1,2,3, *}$

1. The University of Queensland, School of Chemistry and Molecular Biosciences, St Lucia, QLD 4072, Australia.

2. The University of Queensland, Institute for Molecular Bioscience, St Lucia, QLD 4072, Australia.

3. The University of Queensland, School of Pharmacy, Woolloongabba, QLD 4102, Australia.

* Author to whom correspondence should be addressed; email: i.toth@uq.edu.au. 


\begin{abstract}
Fmoc-solid phase peptide synthesis (SPPS) is the most common approach used to synthesize natural and unnatural peptides. However, the synthesis of sequences longer than 30-60 amino acids is associated with a drastic reduction in peptide quality. Thus, large and complex peptides are normally synthesized as fragments, which are then conjugated together. Here, we describe the synthesis of a large, branched peptide: a multi-epitope vaccine candidate against Group A Streptococcus, with the help of microwave assisted Fmoc-SPPS, thiol-maleimide conjugation and copper(I)-catalyzed alkyne-azide cycloaddition (CuAAC) “click" reaction.
\end{abstract}

Key words: Branched peptide synthesis, Copper-catalyzed azide-alkyne cycloaddition click reaction, Fmoc-solid phase peptide synthesis, Group A Streptococcus, Microwave-assisted SPPS, Peptide-based vaccine, Thiol-maleimide conjugation 


\section{Introduction}

Optimal peptide-based vaccines are built based on the minimal amount of antigenic fragments of proteins that are able to induce protective immune responses. The use of synthetic peptide instead of microorganisms, toxins or proteins, allows for the production of a fully-defined vaccine without the potential for biological contamination [1]. The presence of only minimal epitope in vaccine formulations greatly reduces the risk of autoimmune and allergic responses in patients. For example, in the development of Group A Streptococcus (GAS) vaccines, the M-protein-based vaccine approach failed due to the protein's similarity with heart tissue and its ability to trigger autoimmune responses [2,3]. In contrast, peptide-based vaccines that use minimal B-cell epitopes have been proven to be safe and have reached clinical trials [4] [5]. However, minimal epitope alone cannot induce strong immune responses [5].

To improve the immunogenicity of peptide-based vaccines, B-cell epitopes are typically administered together with an adjuvant, and conjugated in larger constructs [1]. The use of multiple epitopes allows for the induction of immune responses against a wider variety of GAS strains. In our study, we aimed to investigate a vaccine carrying three different B-cell epitopes: J8 (QAEDKVKQSREAKKQVEKALKQLEDKVQ), 88/30 (DNGKAIYERARERALQELGP) and NS1 (RVTTRSQAQDAAGLKEKAD) from the conserved and variable M-protein region. The vaccine was designed based on the self-adjuvanting lipid core peptide (LCP) delivery system [6,7]. The pan DR helper T-lymphocyte epitope (PADRE, AKFVAAWTLKAAA) was also incorporated into the vaccine to elicit a T-helper immune response [8,9]. Finally, the dendritic cell targeting peptide (DCpep, FYPSYHSTPQRP) was introduced to further enhance immunological responses [10,11].

In this protocol, the synthesis of the GAS vaccine candidate is presented (Fig 1). The protocol includes five parts: (1) Fmoc-SPPS of Peptide 3; (2) Fmoc-SPPS of Peptide 4; (3) Fmoc-SPPS of Peptide 5; (4) synthesis of Peptide 6 via thiol-maleimide conjugation between Peptides 3 and 4; and (5) synthesis of the final vaccine candidate, Peptide 7, via CuAAC click reaction between Peptides 5 and 6. 


\section{Materials}

Prepare all solutions using peptide synthesis/chromatography grade chemicals and ultrapure water (prepared by a MilliQ water system with a sensitivity of $18.1 \mathrm{M} \Omega-\mathrm{cm}$ at $25^{\circ} \mathrm{C}$ ) at room temperature, unless stated otherwise.

2.1 Stepwise synthesis of Peptide 3 via microwave assisted SPPS

1. Rink amide methylbenzhydrylamine (MBHA) resin, substitution $0.38 \mathrm{mmol} / \mathrm{g} ; 100$ 200 mesh) (see Note 1).

2. 9-Fluorenylmethyloxycarbonyl (Fmoc)-protected L-amino acids.

3. 2-[[1-(4,4-Dimethyl-2,6-dioxocyclohexylidene)ethyl]amino]-hexadecanoic acid (Dde$\mathrm{C} 16-\mathrm{OH})$ (see Note 2).

4. 6-Maleimidohexanoic acid.

5. N,N-dimethylformamide (DMF), dichloromethane (DCM) and methanol.

6. Fmoc-deprotection solution A: piperidine/DMF (20:80\% v/v) solution.

7. $0.5 \mathrm{M}$ 1-[Bis(dimethylamino)methylene]-1H-1,2,3-triazolo[4,5-b] pyridinium 3-oxid hexafluorophosphate (HATU) solution in DMF.

8. $N, N$-Diisopropylethylamine (DIPEA).

9. Capping solution: acetic anhydride/DIPEA/DMF (5:5:90\% v/v/v).

10. Dde-deprotection solution: hydrazine in DMF (5\% v/v).

11. 1-(4,4-Dimethyl-2,6-dioxocyclohex-1-ylidene)-3-methylbutyl (ivDde)-deprotection solution: hydrazine in DMF (2\% v/v).

12. 4-Methyltrityl (Mtt)-deprotection solution: DCM/trifluoroacetic acid (TFA)/triisopropsaline (TIPS) $(98: 1: 1 \% \mathrm{v} / \mathrm{v} / \mathrm{v})$.

13. Cleavage cocktail A: TFA/water/TIPS (95:2.5:2.5\% v/v/v) (see Note 3).

14. Diethyl ether: hexane (80:20\% v/v).

15. Solvent A: ultrapure water with TFA $(0.1 \% \mathrm{v} / \mathrm{v})$.

16. Solvent B: acetonitrile/ultrapure water/TFA (90:10:0.1\% v/v/v).

2.2 Synthesis of Peptide 4 via microwave-assisted SPPS

1. Regents listed previously. 
2. Fmoc-deprotection solution $\mathrm{B}$ : piperidine/DMF $(20: 80 \% \quad \mathrm{v} / \mathrm{v})$ with $0.1 \mathrm{M}$ hydroxybenzotriazole (HOBt) or piperidne/DMF/formic acid (20:75:5\% v/v/v) (see Note 4).

3. 2-Azidoacetic acid

4. Cleavage cocktail B: TFA/1,2-ethanedithiol (EDT)/water/TIPS (94:2.5:2.5:1\% v/v/v/v) (see Note 3).

5. Diethyl ether.

6. Sodium hypochlorite $5 \%$ aqueous solution.

2.3 Synthesis of Peptide 5 via microwave assisted SPPS

1. Regents listed previously.

2. 4-Pentynoic acid.

2.4 Thiol-maleimide conjugation between Peptide 3 and Peptide 4

1. Dimethyl sulfoxide (DMSO).

2. Guanidine buffer (containing $6 \mathrm{M}$ guanidine, $50 \mathrm{mM}$ sodium phosphate buffer, $5 \mathrm{mM}$ EDTA, $20 \%$ acetonitrile in water, $\mathrm{pH}=7.3$ ).

3. $5 \%$ sodium hydroxide $(\mathrm{NaOH})$ aqueous solution.

4. Solvent A and solvent B.

2.5 CuAAC click reaction between Peptide 5 and Peptide 6

1. Methanol/water $(50: 50 \% \mathrm{v} / \mathrm{v})$ solution.

2. $0.04 \mathrm{M} \mathrm{CuSO}_{4}$ aqueous solution.

3. $0.08 \mathrm{M}$ sodium carbonate aqueous solution and $0.16 \mathrm{M}$ ascorbic acid aqueous solution.

4. Solvent A and Solvent B.

\subsection{Equipment}

1. Laboratory glassware.

2. Glass peptide synthesis vessel. (see Note 5, Fig 2).

3. UV-Vis spectrometer.

4. Rotary shaker, magnetic stirrer, balance, microbalance, rotary evaporator, centrifuge and freeze dryer.

5. Microwave peptide synthesizer with open-vessel solid-phase synthesis ability. 
6. Analytical, preparative and semi-preparative reverse-phase-high-performance liquid chromatography (RP-HPLC) system with C18 column or C4 column.

7. Electrospray ionization mass spectrum (ESI-MS).

\section{Methods}

\subsection{Synthesis of Peptide 3}

\section{Synthesis of Resin-Peptide 1}

1. Resin swelling: Transfer the rink amide-MBHA resin $(530 \mathrm{mg}, 0.20 \mathrm{mmol})$ into a glass peptide synthesis vessel (see Note 5). Add DMF ( 10 mL) to the resin, place the vessel on a rotary shaker and shake for $2 \mathrm{~h}$.

2. Remove DMF via filtration under vacuum. Wash once with DMF.

3. Fmoc-deprotection: Add Fmoc-deprotection solution A $(5 \mathrm{~mL})$ with a pipette and shake the mixture on a rotary shaker for $5 \mathrm{~min}$. Remove the reaction mixture via filtration under vacuum and add another portion of deprotection solution for $10 \mathrm{~min}$. Remove the solution under vacuum filtration and wash the resin with DMF $(7 \times 20 \mathrm{~mL})$ (see Note 6).

4. Amino acid preactivation: Weigh out Dde-C16-OH (366 mg, $0.84 \mathrm{mmol}$ ) into a scintillation vial. Add 0.5 M HATU solution (1.6 mL, $0.20 \mathrm{mmol})$, DIPEA (216 $\mu \mathrm{L}$, $1.24 \mathrm{mmol})$ and DMF (3 mL). Swirl the mixture with hand vortex or sonicate until the amino acid solution is completely clear (see Note 7).

5. Add the preactivated lipoamino acid from step 4 to the drained resin and shake the mixture for $1 \mathrm{~h}$ on a rotary shaker. Remove the reaction solution via filtration under vacuum and wash with DMF $(1 \times 15 \mathrm{~mL})$.

6. Repeat steps $4-5$ (double coupling). Wash the resin with DMF $(7 \times 15 \mathrm{~mL})$ (see Note 7).

7. Capping: Add $5 \mathrm{~mL}$ freshly prepared capping solution to the drained resin and shake the mixture for $20 \mathrm{~min}$ on a rotary shaker (see Note 8). Drain the solution and wash the resin with DMF $(7 \times 15 \mathrm{~mL})$.

8. Dde-deprotection: Add Dde-deprotection solution $(10 \mathrm{~mL})$ to the drained resin, cover the synthesis vessel with aluminum foil, and shake the mixture for $15 \mathrm{~min}$ on a rotary shaker (see Note 9). Remove the reaction mixture via filtration under vacuum and wash with DMF $(1 \times 15 \mathrm{~mL})$.

9. Repeat step 8 until $\mathrm{OD}_{290}<0.1$ intensity (a. u.) (see Note 10). 
10. Wash the resin with DMF $(7 \times 15 \mathrm{~mL})$.

11. Repeat steps $\mathbf{4 - 1 0}$ for the second Dde-C16-OH coupling.

12. Transfer the resin into the peptide synthesis vessel attached to the microwave SPPS system $($ see Note 11). Wash the resin with DMF $(1 \times 15 \mathrm{~mL})$, then drain the DMF via filtration under vacuum.

13. Amino acid activation: Weigh out Fmoc-Ser(tBu)-OH (322 mg, $0.84 \mathrm{mmol})$ into a scintillation vial. Add 0.5 M HATU solution (1.6 mL, $0.8 \mathrm{mmol})$ and DIPEA (216 $\mu \mathrm{L}$, $1.24 \mathrm{mmol})$. Swirl the mixture with hand vortex or sonicate until the preactivated amino acid solution becomes clear.

14. Add the preactivated amino acid to the resin and assemble the vessel with the thermometer probe. Place the vessel into the microwave and bubble nitrogen gas through. Irradiate the mixture for $5 \mathrm{~min}$ at $70^{\circ} \mathrm{C}$ (see Note 12).

15. Drain the solution and wash the resin and thermometer probe with DMF $(1 \times 15 \mathrm{~mL})$.

16. Repeat step 13 - 15 (double coupling). The irradiation time for the second coupling is $10 \mathrm{~min}$ at $70^{\circ} \mathrm{C}$, except for sensitive amino acids (see Note 12).

17. Fmoc-deprotection with microwave: Wash the resin well with DMF $(7 \times 15 \mathrm{~mL})$, add Fmoc-deprotection solution $\mathrm{A}(5 \mathrm{~mL})$ and irradiate the mixture at $70^{\circ} \mathrm{C}$ for $2 \mathrm{~min}$. Drain the solution and wash with DMF $(1 \times 15 \mathrm{~mL})$.

18. Repeat step 17 with an irradiation time $5 \mathrm{~min}$.

19. Wash the resin well with DMF $(5 \times 15 \mathrm{~mL})$, then drain under vacuum.

20. Repeat steps 13 - 19 an additional 17 times for the following amino acids: FmocSer(tBu)-OH, Fmoc-Lys(Mtt)-OH, Fmoc-Ala-OH, Fmoc-Lys(ivDde)-OH, Fmoc-Ala$\mathrm{OH}$, Fmoc-Pro-OH, Fmoc-Arg(Pbf)-OH, Fmoc-Gln(Trt)-OH, Fmoc-Pro-OH, Fmoc$\operatorname{Thr}(\mathrm{tBu})-\mathrm{OH}$, Fmoc-Ser(tBu)-OH, Fmoc-His(Trt)-OH, Fmoc-Tyr(tBu)-OH, FmocSer(tBu)-OH, Fmoc-Pro-OH, Fmoc-Tyr(tBu)-OH, Fmoc-Phe-OH (see Note 15).

21. To acetylate the $\mathrm{N}$-terminus of the peptide, add freshly prepared capping solution (5 $\mathrm{mL}$ ) to the resin and irradiate the mixture at $70^{\circ} \mathrm{C}$ for $5 \mathrm{~min}$. Drain the solution under vacuum.

22. Repeat step 21 once. Wash the resin with DMF $(7 \times 15 \mathrm{~mL})$.

\section{Synthesis of Resin-Peptide 2}

23. Transfer Resin-Peptide 1 to the glass peptide synthesis vessel (see Note 13). Wash the resin with DMF $(1 \times 15 \mathrm{~mL})$. 
24. Mtt-deprotection: Wash the resin with DCM $(3 \times 15 \mathrm{~mL})$ (see Note 13). Add Mttdeprotection solution $(10 \mathrm{~mL})$ to the resin and shake the mixture for $15 \mathrm{~min}$ on a rotary shaker; monitor the colour change of the solution. Remove the reaction mixture via filtration under vacuum and wash the resin with DCM.

25. Repeat step 24 until the deprotection solution turns from yellow to transparent (see Note 14). Wash the resin well with DCM $(3 \times 15 \mathrm{~mL})$ then DMF $(7 \times 15 \mathrm{~mL})$.

26. Transfer the resin to the microwave synthesis vessel. Wash the resin with DMF $(1 \times 15$ $\mathrm{mL})$.

27. Repeat steps $\mathbf{1 3}$ - $\mathbf{1 9}$ an additional 13 times for the following amino acids: Fmoc-Ala$\mathrm{OH}$, Fmoc-Ala-OH, Fmoc-Ala-OH, Fmoc-Lys(Boc)-OH, Fmoc-Leu-OH, Fmoc$\operatorname{Thr}(\mathrm{tBu})-\mathrm{OH}$, Fmoc-Trp(Boc)-OH, Fmoc-Ala-OH, Fmoc-Ala-OH, Fmoc-Val-OH, Fmoc-Phe-OH, Fmoc-Lys(Boc)-OH, Fmoc-Ala-OH.

28. Acetylate the N-terminus by repeating steps $21-22$.

\section{Synthesis of Peptide 3}

29. Transfer resin-peptide 2 to the glass peptide synthesis vessel covered with aluminum foil $($ see Note 9). Wash the resin with DMF $(1 \times 15 \mathrm{~mL})$.

30. ivDde-deprotection: Add ivDde-deprotection solution $(10 \mathrm{~mL})$ to the resin and shake the mixture for $15 \mathrm{~min}$. Remove the solution by filtration under vacuum and wash with DMF $(1 \times 15 \mathrm{~mL})$.

31. Repeat step 30 until $\mathrm{OD}_{290}<0.1$ intensity (a. u.) (see Note 10).

32. Couple the 6-maleimidohexanoic acid (177 $\mathrm{mg}, 0.84 \mathrm{mmol})$ in the same manner as Dde-C16-OH, following steps 4 - 6.

33. Wash the resin with DMF $(5 \times 15 \mathrm{~mL}), \operatorname{DCM}(5 \times 15 \mathrm{~mL})$ and methanol $(2 \times 15 \mathrm{~mL})$. Dry the resin under vacuum. Transfer the resin to a scintillation vial and measure the weight (see Note 15).

34. Peptide cleavage: Transfer known amount of resin to a scintillation vial and add a stirring bar. Add cleavage cocktail A to the resin $(10 \mathrm{~mL} / \mathrm{g}$ resin) and stir for $3 \mathrm{~h}$ with magnetic stirring at room temperature (see Note 3).

35. Remove the resin by filtration and transfer the clear solution to a round-bottom flask. Remove TFA under reduced pressure in a high-vacuum rotary evaporator with dry iceacetone cooled trap (see Note 16).

36. Add cold ether to the flask and filter out the precipitated crude peptide (see Note 17). After adding cold ether, shake the round-bottom flask and pour the mixture into a funnel 
or syringe with filter to collect the solids. Wash the crude peptide with cold ether once more.

37. Dissolve the peptide with solvent B (10 mL) first, then add 50:50\% v/v solvent A:B (40 $\mathrm{mL}$ ) and sonicate until the solution becomes clear. Transfer the solution to a roundbottom flask, freeze in the dry ice-acetone cold bath, then lyophilize.

38. Dissolve the crude product with $50: 50 \%$ v/v solvent A:B, filter with a $0.45 \mu$ mylon filter and purify the produced Peptide 3 by preparative reverse-phase HPLC (C4 column). The final product is a white solid. Molecular weight: 4166.0 Da. ESI-MS: $[\mathrm{M}+3 \mathrm{H}]^{3+} \mathrm{m} / \mathrm{z}, 1390.3$ (calcd 1389.7), $[\mathrm{M}+4 \mathrm{H}]^{4+} \mathrm{m} / \mathrm{z}, 1042.5$ (calcd 1042.5). RP-HPLC: $t_{\mathrm{R}}=24.7 \mathrm{~min}(0-100 \%$ solvent $\mathrm{B}, 2-32 \mathrm{~min}, \mathrm{C} 4$ column $)$, purity $>95 \%$.

39. Lyophilize Peptide 3, seal the container with parafilm and store at $-20^{\circ} \mathrm{C}$.

\subsection{Synthesis of Peptide 4}

1. Repeat steps 3.1.1 - 3.1.3.

2. Transfer the resin into the peptide synthesis vessel attached to the microwave SPPS system. Wash the resin with DMF $(1 \times 15 \mathrm{~mL})$, then drain the DMF via filtration under vacuum.

3. Repeat steps 3.1.13 - 3.1.16 with Fmoc-Lys(Mtt)-OH.

4. Repeat step 3.1.21 to cap the resin.

5. Repeat steps 3.1.23 - 3.1.25 to remove the Mtt group.

6. Couple 2-azidoacetic acid $(85 \mathrm{mg}, 0.84 \mathrm{mmol})$ in the same manner as Dde-C16-OH following steps 3.1.4 - 3.1.6. Cover the synthesis vessel with aluminum foil (see Note 19).

7. Transfer the resin into the peptide synthesis vessel attached to the microwave SPPS system. Wash the resin with DMF $(1 \times 15 \mathrm{~mL})$, then drain the DMF via filtration under vacuum.

8. Repeat steps 3.1.17 - 3.1.19.

9. Repeat steps 3.1.13 - 3.1.19 an additional 32 times for the following amino acids: Fmoc-Ala-OH, Fmoc-Ala-OH, Fmoc-Ala-OH, Fmoc-Gln(Trt)-OH, Fmoc-Val-OH, Fmoc-Lys(Boc)-OH, Fmoc-Asp(OtBu)-OH, Fmoc-Glu(OtBu)-OH, Fmoc-Leu-OH, Fmoc-Gln(Trt)-OH, Fmoc-Lys(Boc)-OH, Fmoc-Leu-OH, Fmoc-Ala-OH, FmocLys(Boc)-OH, Fmoc-Glu(OtBu)-OH, Fmoc-Val-OH, Fmoc-Gln(Trt)-OH, Fmoc- 
Lys(Boc)-OH, Fmoc-Lys(Boc)-OH, Fmoc-Ala-OH, Fmoc-Glu(OtBu)-OH, Fmoc$\operatorname{Arg}(\mathrm{Pbf})-\mathrm{OH}$, Fmoc-Ser(tBu)-OH, Fmoc-Gln(Trt)-OH, Fmoc-Lys(Boc)-OH, FmocAsp(OtBu)-OH, Fmoc-Glu(OtBu)-OH, Fmoc-Ala-OH, Fmoc-Gln(Trt)-OH, FmocCys(Trt)-OH. Caution: After coupling the first Fmoc-Asp(OtBu)-OH, use Fmocdeprotection solution $\mathrm{B}$ for the rest of the peptide, and irradiate twice at $50^{\circ} \mathrm{C}$ for $5 \mathrm{~min}$ (see Note 19).

10. Repeat step 3.1.33.

11. Repeat steps 3.1.34 - 3.1.36 with cleavage cocktail B (see Notes 3, 17 and 20).

12. Dissolve the peptide with $50: 50 \% \mathrm{v} / \mathrm{v}$ solvent A:B $(50 \mathrm{~mL})$ and sonicate until the solution becomes clear. Transfer the solution to a round-bottom flask, freeze in the dry ice-acetone cold bath, then lyophilize.

13. Dissolve the product with $50: 50 \%$ v/v solvent $A: B$, filter with a $0.45 \mu$ m nylon filter and purify the product by preparative reverse-phase HPLC (C18 column). The final product, Peptide 4, is a white solid. Molecular weight: 3809.4 Da. ESI-MS: $[\mathrm{M}+3 \mathrm{H}]^{3+}$ $m / z 1271.3$ (calcd 1270.8), [M+4H] ${ }^{4+} m / z 953.3$ (calcd 953.3). RP-HPLC: $t_{\mathrm{R}}=16.1 \mathrm{~min}$ (0-100\% solvent B, 2-32 min, C8 column), purity > 99\%.

14. Lyophilize Peptide 4, seal the container with parafilm and store at $-20^{\circ} \mathrm{C}$.

\section{3 Synthesis of Peptide 5 via microwave assisted SPPS}

1. Repeat steps 3.1.1 - 3.1.3.

2. Repeat steps 3.1.13 - 3.1.19 an additional 32 times for the following amino acids: Fmoc-Asp(OtBu)-OH, Fmoc-Ala-OH, Fmoc-Lys(Boc)-OH, Fmoc-Glu(OtBu)-OH, Fmoc-Lys(Boc)-OH, Fmoc-Leu-OH, Fmoc-Gly-OH, Fmoc-Ala-OH, Fmoc-Ala-OH, Fmoc-Asp(OtBu)-OH, Fmoc-Gln(Trt)-OH, Fmoc-Ala-OH, Fmoc-Gln(Trt)-OH, FmocSer(tBu)-OH, Fmoc-Arg(Pbf)-OH, Fmoc-Thr(tBu)-OH, Fmoc-Thr(tBu)-OH, FmocVal-OH, Fmoc-Arg(Pbf)-OH, Fmoc-Pro-OH, Fmoc-Gly-OH, Fmoc-Leu-OH, FmocGlu(OtBu)-OH, Fmoc-Gln(Trt)-OH, Fmoc-Leu-OH, Fmoc-Ala-OH, Fmoc-Arg(Pbf)$\mathrm{OH}$, Fmoc-Glu(OtBu)-OH, Fmoc-Arg(Pbf)-OH, Fmoc-Ala-OH, Fmoc-Arg(Pbf)-OH, Fmoc-Glu(OtBu)-OH, Fmoc-Tyr(tBu)-OH, Fmoc-Ile-OH, Fmoc-Ala-OH, FmocLys(Boc)-OH, Fmoc-Gly-OH. Caution: After coupling the first Fmoc-Asp(OtBu)-OH, use Fmoc-deprotection solution B for the rest of the peptide, and irradiate twice at $50^{\circ} \mathrm{C}$ for 5 min (see Note 19). 
3. Transfer the resin to the glass peptide synthesis vessel. Wash the resin with DMF $(1 \times$ $15 \mathrm{~mL})$.

4. Couple 4-pentynoic acid $(82 \mathrm{mg}, 0.84 \mathrm{mmol})$ in the same manner as Dde-C16-OH, following steps 3.1.4 - 3.1.6 (see Note 11).

5. Repeat steps 3.1.33- 3.1.36.

6. Repeat step 3.2.13.

7. Dissolve the product with $50: 50 \% \mathrm{v} / \mathrm{v}$ solvent $\mathrm{A}: \mathrm{B}$, filter with a $0.45 \mu \mathrm{m}$ nylon filter and purify the product by preparative reverse-phase HPLC (C18 column). The final product, Peptide 5, is a white solid. Molecular weight: 4449.9 Da. ESI-MS: $[\mathrm{M}+3 \mathrm{H}]^{3+}$ $m / z 1484.9$ (calcd 1484.3), $[\mathrm{M}+4 \mathrm{H}]^{4+} \mathrm{m} / z 1113.7$ (calcd 1113.5), $[\mathrm{M}+5 \mathrm{H}]^{5+} \mathrm{m} / z 891.5$ (calcd 891.0). RP-HPLC: $t_{\mathrm{R}}=14.4 \mathrm{~min}(0-100 \%$ solvent $\mathrm{B}, 2-32 \mathrm{~min}, \mathrm{C} 4$ column), purity $>99 \%$.

8. Lyophilize Peptide 5, seal the container with parafilm and store at $-20^{\circ} \mathrm{C}$.

\subsection{Thiol-maleimide conjugation between Peptide 3 and Peptide 4}

1. Weigh out Peptide 4 (3.8 mg, $1 \mu \mathrm{mol})$ and Peptide $3(8.3 \mathrm{mg}, 2 \mu \mathrm{mol})$ into two $2 \mathrm{~mL}$ flasks.

2. Separately dissolve both peptides with $10 \mu \mathrm{L}$ DMSO (see Note 21), then add $300 \mu \mathrm{L}$ guanidine buffer to each.

3. Transfer Peptide 4 to Peptide 3 and mix well with a pipette.

4. Add $5 \% \mathrm{NaOH}$ aqueous solution to adjust the $\mathrm{pH}$ to 7.2 (see Note 22).

5. Seal the flask with a rubber stopper.

6. Prepare a balloon with nitrogen gas and insert into the rubber stopper with a needle. Insert another needle and flow nitrogen for $15 \mathrm{~s}$ to replace the air with nitrogen gas.

7. Place the flask in an incubator and shake $(70 \mathrm{rpm})$ at $37^{\circ} \mathrm{C}$ for $2 \mathrm{~h}$.

8. Filter the solution with a $0.45 \mu \mathrm{m}$ nylon filter.

9. Purify the product by directly injecting the solution into a semi-preparative reversephase HPLC (C4 column). The final product, Peptide 6, is a white solid. Molecular weight: 7975.4 Da. ESI-MS: $[\mathrm{M}+5 \mathrm{H}]^{5+} \mathrm{m} / \mathrm{z} 1596.6$ (calcd 1596.1), $[\mathrm{M}+6 \mathrm{H}]^{6+} \mathrm{m} / \mathrm{z}$ 1330.5 (calcd 1330.2), $[\mathrm{M}+7 \mathrm{H}]^{7+} \mathrm{m} / \mathrm{z} 1140.7$ (calcd 1140.3), $[\mathrm{M}+8 \mathrm{H}]^{8+} \mathrm{m} / \mathrm{z}, 997.9$ (calcd 997.9), $[\mathrm{M}+9 \mathrm{H}]^{9+} \mathrm{m} / z 887.1$ (calcd 887.2). RP-HPLC: $t_{\mathrm{R}}=21.0 \mathrm{~min}(0-100 \%$ solvent B, 2-32 min, C4 column), purity $>95 \%$.

10. Lyophilize Peptide 7 , seal the container with parafilm and store at $-20^{\circ} \mathrm{C}$. 


\subsection{CuAAC click reaction between Peptide 5 and Peptide 6}

1. Weigh out Peptide $6(6.1 \mathrm{mg}, 0.5 \mu \mathrm{mol})$ and Peptide 5 ( $4.5 \mathrm{mg}, 1 \mu \mathrm{mol})$ into two 2 mL flasks. Add $700 \mu \mathrm{L}$ methanol/water (50:50\% v/v) solution to both flasks to dissolve.

2. Transfer Peptide 5 and Peptide 6 to a $5 \mathrm{~mL}$ flask and mix well with a pipette.

3. Prepare $0.8 \mathrm{M}$ sodium ascorbate aqueous solution: Mix $0.08 \mathrm{M}$ sodium carbonate aqueous solution $(0.5 \mathrm{~mL})$ and $0.16 \mathrm{M}$ ascorbic acid aqueous solution $(0.5 \mathrm{~mL})$. Swirl the mixture by hand vortex and sonicate. Use immediately after prepared.

4. Add freshly prepared $0.08 \mathrm{M}$ sodium ascorbate aqueous solution $(50 \mu \mathrm{L}, 4 \mu \mathrm{mol})$ to the mixture.

5. Add $0.04 \mathrm{M} \mathrm{CuSO}_{4}$ aqueous solution $(50 \mu \mathrm{L}, 2 \mu \mathrm{mol})$ to the mixture (see Note 23 ).

6. Repeat steps 3.4.5 - 3.4.7.

7. Transfer the mixture to a scintillation vial, add $10 \mathrm{~mL}$ water to dissolve the precipitations and lyophilize to get the crude product.

8. Dissolve the product with $50: 50 \% \mathrm{v} / \mathrm{v}$ solvent $\mathrm{A}: \mathrm{B}$, filter with a $0.45 \mu \mathrm{m}$ nylon filter and purify by semi-preparative reverse-phase HPLC (C4 column). The final product, Peptide 7, is a white solid. Molecular weight: 12425.3 Da. ESI-MS: $[\mathrm{M}+12 \mathrm{H}]^{12+} \mathrm{m} / \mathrm{z}$ 1036.3 (calcd 1036.4), $[\mathrm{M}+13 \mathrm{H}]^{13+} \mathrm{m} / \mathrm{z} 958.5$ (calcd 956.8), $[\mathrm{M}+14 \mathrm{H}]^{14+} \mathrm{m} / \mathrm{z} 888.4$ (calcd 888.5), $[\mathrm{M}+15 \mathrm{H}]^{15+} \mathrm{m} / \mathrm{z} 829.4$ (calcd 829.3), $[\mathrm{M}+16 \mathrm{H}]^{16+} \mathrm{m} / \mathrm{z} 777.7$ (calcd 777.6). RP-HPLC: $t_{\mathrm{R}}=20.1 \mathrm{~min}(0-100 \%$ solvent $\mathrm{B}, 2-32 \mathrm{~min}, \mathrm{C} 4$ column$)$, purity > $95 \%$.

9. Lyophilize Peptide 7 , seal the container with parafilm and store at $-20^{\circ} \mathrm{C}$. 


\section{Notes}

1 Resin with substitution below $0.5 \mathrm{mmol} / \mathrm{g}$ can be used to synthesize the branching peptide. Check with the supplier for the substitution and calculate the amount of the resin required.

2 This lipoamino acid can be purchased with CAS No. 1160439-00-8, or produced according to our previously published protocol [12].

3 Cleavage cocktail A is only used to cleave the peptide from the resin when cysteine is not present in the sequence. If cysteine is present, use cleavage cocktail B.

4 Fmoc-deprotection solution A is only used to remove Fmoc from the peptide when aspartic acid is not present in the sequence. If aspartic acid is present, use Fmoc-deprotection solution B following the first aspartic acid coupling.

5 The glass peptide synthesis vessel is a $\sim 20 \mathrm{~mL}$ cylinder-shaped glass separation funnel with a fritted filter disc to support resin, and screwcap closure at the top (Fig 2).

6 Important. Proper washing of the resin between deprotection and coupling steps is very important to avoid side reactions. Fill the washing bottle with DMF. Connect the synthesis vessel to the vacuum, remove the cap, turn on the tap and rinse the vessel cap with DMF. The solution will drain under vacuum and wash the surface of the vessel. Close the tap and fill the vessel with DMF, and repeat the process six times. If an aggregation of resin appears, stir the solution with a glass rod, or fill the vessel with DMF, put the cap on, and shake the vessel to disaggregate the resin. After washing, close the tap and place the cap on. Do not keep the resin dry between washes (or any other steps) for longer than a few seconds.

7 Some lipoamino acids and Fmoc-protected amino acids may not be easily dissolved/activated under this condition. In this case, add an additional 2-3 mL DMF and sonicate until clear. Lipoamino acids are less reactive, so their preactivating process should be 5 min longer than for other amino acids.

8 Acetylation capping after coupling is aimed to permanently cap the unreacted amine groups, and it is compulsory after coupling the first amino acid. Capping can also be performed after any bulky (problematic) amino acid coupling.

9 Dde/ivDde-deprotection: Hydrazine is sensitive to heat and light, so the tubes and vessels containing Dde should be covered by aluminum foil. Hydrazine can also deprotect the Fmoc protection group, so check the sequence to make sure no Fmoc groups are present.

Cation: hydrazine is toxic. 
10 To check the completion of Dde/ivDde deprotection, collect the reacted solution via filtration in a $1 \mathrm{~cm} \times 1 \mathrm{~cm}$ quartz UV cuvette and measure the $\mathrm{OD}_{290}$ with UV spectrometer. Repeat until the $\mathrm{OD}_{290}<0.1$ intensity (a. u.). Dde deprotection is always finished within 3 $\mathrm{h}$; ivDde deprotection needs more than $18 \mathrm{~h}$.

11 A microwave synthesizer can be used in the deprotection and coupling steps and can sometimes make the coupling more efficient. Do not use microwave irradiation to couple chemicals that are not resistant to heat or that are explosive at high temperature (e.g. 2azidoacetic acid, 4-pentynoic acid, 6-maleimidehexanoic acid). Check the user's manual for the operation and safety instruction of the microwave system. When washing the resin in the microwave synthesis vessel, the thermometer probe should be also washed.

12 Special irradiation procedure should be applied for Fmoc-Arg(Pbf)-OH, Fmoc-His(Trt)$\mathrm{OH}$ and Fmoc-Cys(Trt)-OH. Following the addition of preactivated Fmoc-Arg(Pbf), mix with $\mathrm{N}_{2}$ bubbling at room temperature for $5 \mathrm{~min}$, then irradiate at $70^{\circ} \mathrm{C}$ for $10 \mathrm{~min}$. For Fmoc-His(Trt)-OH and Fmoc-Cys(Trt)-OH: mix with $\mathrm{N}_{2}$ bubbling at room temperature for $5 \mathrm{~min}$, then irradiate at $50^{\circ} \mathrm{C}$ for $10 \mathrm{~min}$.

$13 \mathrm{DCM}$ has a low boiling point $\left(40^{\circ} \mathrm{C}\right)[13]$, thus, this reaction can only be performed at room temperature.

14 The removal of the Mtt group from a peptide will result in the Mtt-deprotection solution colour change from transparent to yellow to transparent; this colour change can be used to indicate completion. To check the colour, use a sheet of white paper for the background. After deprotection, remove a small amount of resin via pipette, transfer the resin to a microtube and add drops of neat TFA. If the solution does not become yellow, this suggests that the Mtt group has been fully removed.

15 To store the resin long-term, seal the scintillation vial with parafilm and store at $-20^{\circ} \mathrm{C}$.

16 Evaporation to dry is not required; the water and TIPS in the cleavage cocktail are hard to remove under this condition.

17 For peptides containing lipids, a mixture of 20:80 v/v hexane/diethyl ether is recommended for precipitation. After adding cold hexane/ether or neat diethyl ether, shake the roundbottom flask and filter the mixture to collect the solid. Wash the solid once with cold ether.

18 2-Azidoacetic acid is sensitive to light and heat. The coupling should be performed at room temperature within a vessel covered by aluminum foil. Caution: 2-azidoacetic acid is explosive during heating when iron or salt is present $[14,15]$. Iron contamination could come from laboratory spoons or other metal equipment. 
19 The aspartic acid residue in the peptide sequence easily forms aspartimide during Fmocdeprotection. Therefore, Fmoc-deprotection solution B should be used in deprotection following the coupling of the first aspartic acid. Caution: Explosions have been reported during $\mathrm{HOBt}$ heating. The irradiation temperature should be $50^{\circ} \mathrm{C}[16]$.

20 This TFA cleavage cocktail formula is for peptides containing cysteine. EDT is used as a scavenger. EDT transfers a strong odor and all glassware and disposables contaminated with EDT should be bleached with 5\% sodium hypochlorite solution overnight before removal from the fume hood.

21 The peptide should be fully dissolved in DMSO. If required, add more DMSO and sonicate.

$22 \mathrm{pH}$ can be measured with $\mathrm{pH}$ indicator paper.

23 After adding sodium ascorbate, a light-blue to yellow-brown colour change is observed and a white cloudy solid (product) immediately begins to precipitate.

\section{Figure captions}

Fig 1: Synthesis of a multi-epitope vaccine candidate against GAS.

Fig 2: The peptide synthesis vessel. 


\section{References}

1. Skwarczynski M, Toth I (2016) Peptide-based synthetic vaccines. Chem Sci 7 (2):842-854. doi: $10.1039 / \mathrm{c} 5 \mathrm{sc} 03892 \mathrm{~h}$

2. Massell BF (1969) Rheumatic Fever Following Streptococcal Vaccination. Jama 207 (6). doi:10.1001/jama.1969.03150190037007

3. Marijon E, Mirabel M, Celermajer DS, Jouven X (2012) Rheumatic heart disease. Lancet 379 (9819):953-964. doi:10.1016/s0140-6736(11)61171-9

4. Rajčáni J, Szathmary S (2018) Peptide Vaccines: New Trends for Avoiding the Autoimmune Response. Open Infect Dis J 10 (1):47-62. doi:10.2174/1874279301810010047

5. Li W, Joshi MD, Singhania S, Ramsey KH, Murthy AK (2014) Peptide Vaccine: Progress and Challenges. Vaccines (Basel) 2 (3):515-536. doi:10.3390/vaccines2030515

6. Skwarczynski M, Toth I (2011) Lipid-core-peptide system for self-adjuvanting synthetic vaccine delivery. Methods Mol Biol 751:297-308. doi:10.1007/978-1-61779-151-2_18

7. Zhong W, Skwarczynski M, Toth I (2009) Lipid Core Peptide System for Gene, Drug, and Vaccine Delivery. Aust J Chem 62 (9):956-967. doi:10.1071/ch09149

8. Moyle PM, Toth I (2013) Modern subunit vaccines: development, components, and research opportunities. ChemMedChem 8 (3):360-376. doi:10.1002/cmdc.201200487

9. Alexander J, Sidney J, Southwood S, Ruppert J, Oseroff C, Maewal A, Snoke K, Serra HM, Kubo RT, Sette A, Grey HM (1994) Development of high potency universal DR-restricted helper epitopes by modification of high affinity DR-blocking peptides. Immunity 1 (9):751761. doi:10.1016/s1074-7613(94)80017-0

10. Erskine CL, Krco CJ, Hedin KE, Borson ND, Kalli KR, Behrens MD, Heman-Ackah SM, von Hofe E, Wettstein PJ, Mohamadzadeh M, Knutson KL (2011) MHC class II epitope nesting modulates dendritic cell function and improves generation of antigen-specific CD4 helper T cells. J Immunol 187 (1):316-324. doi:10.4049/jimmunol.1100658

11. Moyle PM, Hartas J, Henningham A, Batzloff MR, Good MF, Toth I (2013) An efficient, chemically-defined semisynthetic lipid-adjuvanted nanoparticulate vaccine development system. Nanomedicine 9 (7):935-944. doi:10.1016/j.nano.2013.01.009

12. Ahmad Fuaad AA, Skwarczynski M, Toth I (2016) The Use of Microwave-Assisted SolidPhase Peptide Synthesis and Click Chemistry for the Synthesis of Vaccine Candidates Against Hookworm Infection. Methods Mol Biol 1403:639-653. doi:10.1007/978-1-4939-3387-7_36

13. Celebioglu A, Uyar T (2011) Electrospun porous cellulose acetate fibers from volatile solvent mixture. Mater Lett 65 (14):2291-2294. doi:10.1016/j.matlet.2011.04.039

14. Dyke JM, Groves AP, Morris A, Ogden JS, Dias AA, Oliveira AMS, Costa ML, Barros MT, Cabral MH, Moutinho AMC (1997) Study of the Thermal Decomposition of 2Azidoacetic Acid by Photoelectron and Matrix Isolation Infrared Spectroscopy. J Am Chem Soc 119 (29):6883-6887. doi:10.1021/ja964354v

15. Bretherick L (1990) Specific Chemicals. In: Bretherick's Handbook of Reactive Chemical Hazards. Butterworth-Heinemann, pp 1-1475. doi:10.1016/b978-0-7506-0706-3.50009-2

16. Wehrstedt KD, Wandrey PA, Heitkamp D (2005) Explosive properties of 1hydroxybenzotriazoles. J Hazard Mater 126 (1-3):1-7. doi:10.1016/j.jhazmat.2005.05.044 
Figure 1 Synthesis of a multi-epitope vaccine candidate against GAS.

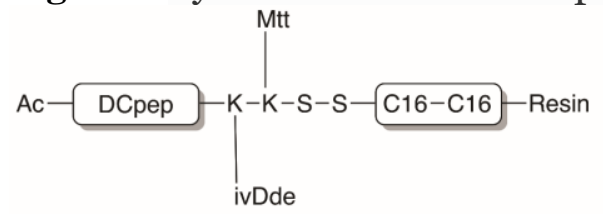

Resin-Peptide 1

1. Remove Mtt

2. Couple amino acids

$\checkmark$

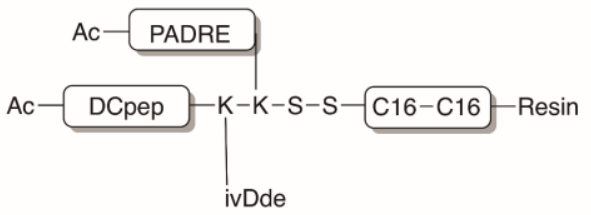

Resin-Peptide 2

2. Couple 6-maleimidohexanoic acid

3. Cleavage from resin.

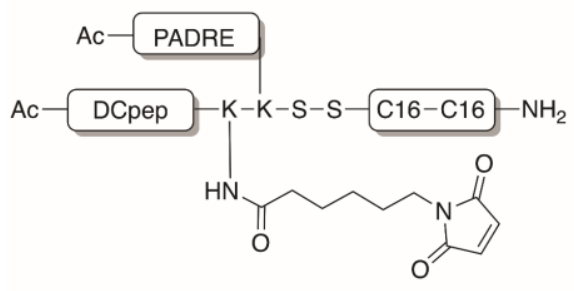

Peptide 3

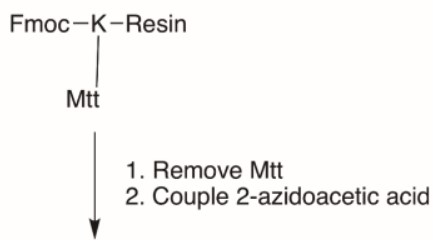

Fmoc-K-Resin

HN<smiles>NCC(N)=O</smiles>

Couple amino acids. 2. Cleavage from resin.

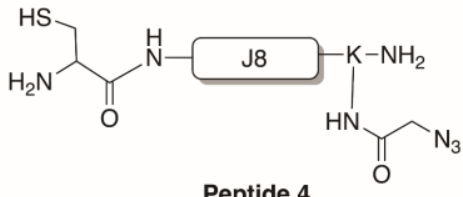

Peptide 4
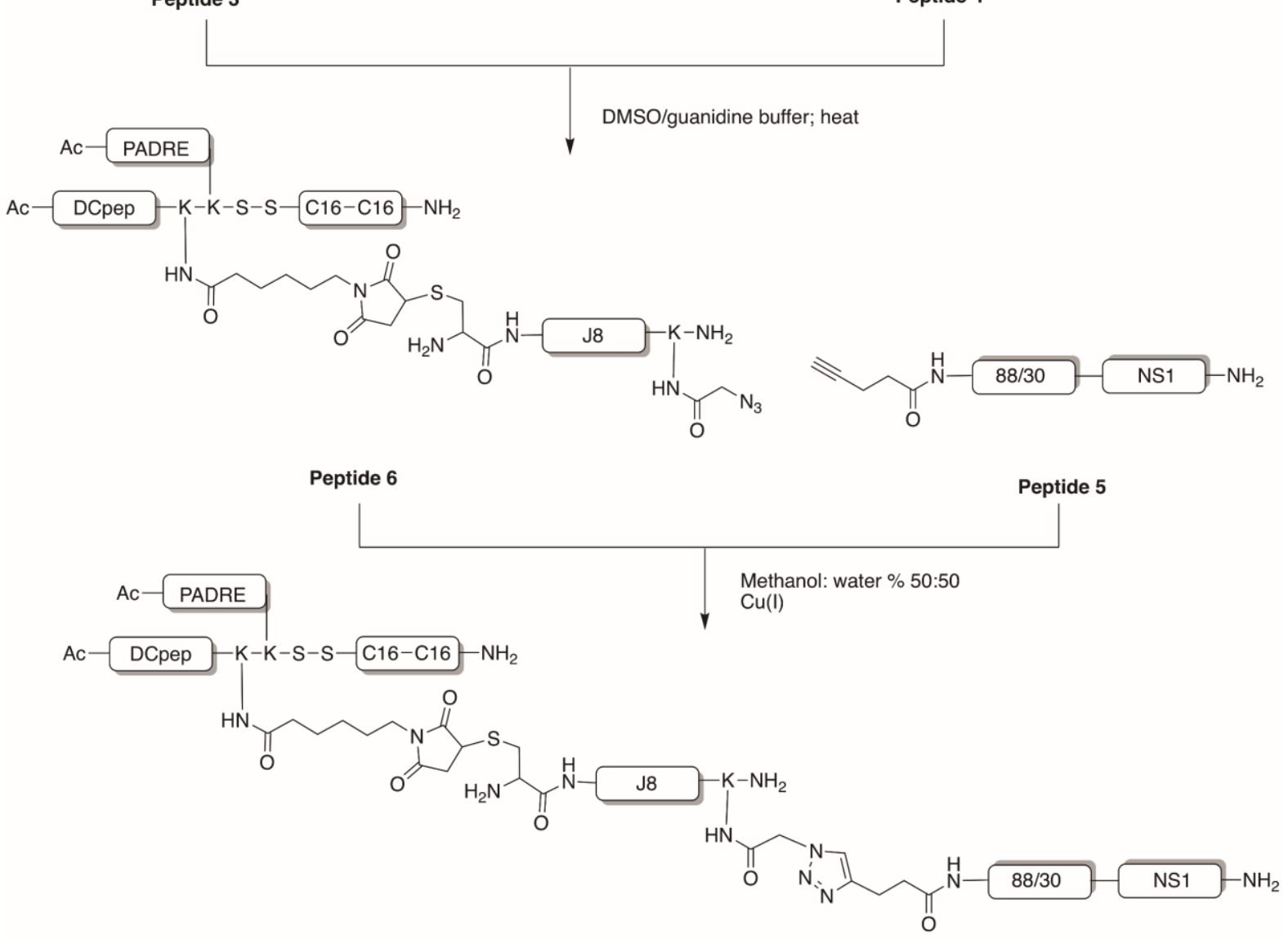

Peptide 7 
Figure 2 The peptide synthesis vessel.

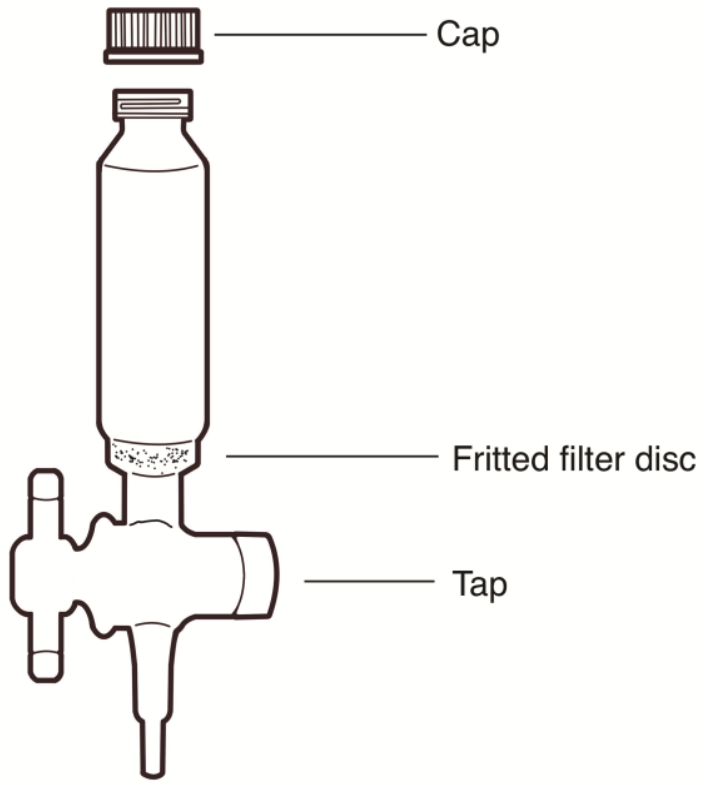

